\title{
Exposure assessment of radon in the drinking water supplies: a descriptive study in Palestine
}

\author{
Hamzeh Al Zabadi ${ }^{*}$, Samar Musmar ${ }^{2}$, Shaza Issa ${ }^{2}$, Nidal Dwaikat ${ }^{3}$ and Ghassan Saffarini ${ }^{3}$
}

\begin{abstract}
Background: Radon gas is considered as a main risk factor for lung cancer and found naturally in rock, soil, and water. The objective of this study was to determine the radon level in the drinking water sources in Nablus city in order to set up a sound policy on water management in Palestine.

Methods: This was a descriptive study carried out in two phases with a random sampling technique in the second phase. Primarily, samples were taken from 4 wells and 5 springs that supplied Nablus city residents. For each source, 3 samples were taken and each was analyzed in 4 cycles by RAD 7 device manufactured by Durridge Company. Secondly, from the seven regions of the Nablus city, three samples were taken from the residential tap water of each region. Regarding the old city, ten samples were taken. Finally, the mean radon concentration value for each source was calculated.

Results: The mean (range) concentration of radon in the main sources were 6.9 (1.5-23.4) Becquerel/liter (Bq/L). Separately, springs and wells' means were $4.6 \mathrm{~Bq} / \mathrm{L}$ and $9.5 \mathrm{~Bq} / \mathrm{L}$; respectively. For the residential tap water in the 7 regions, the results of the mean (range) concentration values were found to be 1.0 (0.9-1.3) Bq/L. For the old city, the mean (range) concentration values were 2.3 (0.9-3.9) Bq/L.

Conclusions: Except for Al-Badan well, radon concentrations in the wells and springs were below the United State Environmental Protection Agency maximum contaminated level (U.S EPA MCL). The level was much lower for tap water. Although the concentration of radon in the tap water of old city were below the $\mathrm{MCL}$, it was higher than other regions in the city. Preventive measures and population awareness on radon's exposure are recommended.
\end{abstract}

\section{Background}

Radon is a colorless, odorless and tasteless gas. It is a chemically and biologically inert noble gas with a heavily neutron-rich nucleus that makes it a radioactive element [1]. It has three main natural isotopes; radon-222 ( $\mathrm{Rn}-222) ;$ radon-220 (Rn-220 also known as thoron); and radon-219 (Rn-219) [2]. Rocky, mountainous regions and phosphate rich soil regions and water, all over the world, tend to have varying amounts of $\mathrm{Rn}-222$ $[3,4]$. Radon is unstable and breaks down into radon progeny emitting highly ionizing alpha radiation which is very harmful to humans when they are inhaled or swallowed [5].

Radon comes mainly from the soil underneath the building. However, the primary routes of potential

\footnotetext{
* Correspondence: halzabadi@gmail.com

'Public Health and Community Medicine Department, Faculty of Medicine and Health Sciences, An-Najah National University, Nablus, Palestine Full list of author information is available at the end of the article
}

human exposure to radon are inhalation radon gas and ingestion of water-dissolved radon [4]. Radon in the groundwater or building materials enters the working and living spaces and disintegrates into its decay products. Although high concentrations of radon in groundwater may contribute to radon exposure through ingestion, the exposure risk through inhalation of radon released from water is usually more significant. Some radon and its progeny in drinking water might be ingested and reach the stomach and intestine. However, inhaled radon into lungs could be readily breathed out through pulmonary circulation [1].

When radon gas is inhaled, the highly-ionizing alpha particles emitted by deposited short-lived decay products of radon Polonium-218 (Po-218) and Polonium214 (Po-214) can interact with the biological tissue in the lungs leading to DNA damage that is considered as an important step in the carcinogenesis process $[6,7]$. In the USA, studies showed that radon in homes

\section{() Biomed Central}


caused 21,100 lung cancer deaths per year making it the second leading cause of lung cancer deaths [7]. In $\mathrm{UK}$, it is estimated to be responsible for about 1,100 deaths per year [8].

Table 1 below shows some international studies that were carried out on different water sources and their measured radon concentration levels. A further study showed that the groundwater sources (springs and wells) were generally more enriched in $\mathrm{Rn}-222$ than surface waters (rivers and streams) [9]. In the Middle East, Jordan for example, a neighboring country to Palestine, a study was performed on the radon level in water [10]. The concentration of $\mathrm{Rn}-222$ ranged from 3.3 to 10.7 $\mathrm{Bq} / \mathrm{L}$ (Becquerel/liter) in cold spring water, from 3.2 to $5.5 \mathrm{~Bq} / \mathrm{L}$ in hot spring water, from 3.1 to $5.7 \mathrm{~Bq} / \mathrm{L}$ in well water, from 2.5 to $4.7 \mathrm{~Bq} / \mathrm{L}$ in drinking water and from 4.3 to $6.3 \mathrm{~Bq} / \mathrm{L}$ in the sea water. The study concluded that these measurement levels were within the usual standard limits of radon. In another neighboring country, Lebanon, a study on water sources was performed and found that the water dissolved radon concentrations ranged from a low of $0.91 \mathrm{~Bq} / \mathrm{L}$ in a coastal well source to a high of $49.6 \mathrm{~Bq} / \mathrm{L}$ in a spring source in a mountainous region. Of the 20 sites sampled, only five had radon levels above $11 \mathrm{~Bq} / \mathrm{L}$ (the U.S EPA maximum contaminant level) [11] and these mostly occurred in areas adjacent to well-known geological fault zones. In general, the concentrations found in the previous mentioned studies were all below the 100 and $146 \mathrm{~Bq} / \mathrm{L}$ level proposed by the European Union [12] and the United States alternative maximum contaminant level (AMAL) [11]; respectively.

In Palestine, most studies concerned with the measured indoor radon exposure concentration. For instance, a study was designed to detect the indoor radon concentration in old Nablus city houses [10]. In that study, radon indoor levels were in the normal range according to USA radon safe level [11] but they exceeded the levels found in some Arab countries as Saudi Arabia, for example. Although Palestine has a Mediterranean climate and the people usually use natural ventilation in summer through windows and doors that could lead to relatively low indoor radon concentration in summer, the high indoor radon concentration in that specific region in Palestine (old city) could be explained most probably due to the overcrowding of the old city houses and therefore poor ventilation. In Israel, that share the same environmental conditions with Palestine, a survey was carried out between 1998 and 2003 to determine the indoor radon level [13] showed that there were 6 prone areas for radon according to the ICRP (the International Commission on Radiological Protection) definition. The study concluded that radon measurements and mitigation steps should be taken in public and private dwellings in these areas.

Since radon is a health hazard and a risk factor for some types of cancers including lung cancer [7], many studies have been conducted worldwide to determine its concentration in different environmental media in order to reduce its adverse effects on the human health [9,14-16]. To our knowledge, no study was carried out regarding radon assessment in the drinking water supplies in Palestine. Since people are in a daily-contact with the drinking water, it was reasonable to design a study in order to investigate the radon levels in the drinking water in Palestine to set up a sound policy on water management. Nablus city is one of the most populated cities in the West Bank [17] and therefore it was chosen as the study setting. The results of this study will call upon further analytical studies in the West Bank cities on radon concentration in the drinking water. They may also highlight intervention programs and strategies that could help the decision-makers in the better assessment and evaluation of the safety of the drinking water.

\section{Methods}

\section{Study design}

This was a descriptive study performed on two phases. In the first phase we covered all the wells and springs in Nablus city. In the second phase we selected a randomized sample that represents the residential tap water of the city.

Table 1 Some international studies that were carried out on different water sources and their measured radon concentration levels

\begin{tabular}{|c|c|c|c|c|}
\hline Country & Water source & $\begin{array}{l}\text { Radon } \\
\text { concentration }\end{array}$ & Reference & Notes \\
\hline $\begin{array}{l}\text { United } \\
\text { Kingdom }\end{array}$ & Tap water & $\begin{array}{l}1-2 \mathrm{~Bq} / \mathrm{L} \\
\text { (range) }\end{array}$ & [9] & $\begin{array}{l}\text { The mean radon level was below } 11 \mathrm{~Bq} / \mathrm{L} \text { which is the safe level approved by the } \\
\text { United States Environmental Protection Agency (U.S EPA) [10]. }\end{array}$ \\
\hline Finland & Drill Wells & $\begin{array}{l}130 \mathrm{~Bq} / \mathrm{L} \\
\text { (mean) }\end{array}$ & {$[11]$} & $\begin{array}{l}\text { Aimed to find if there is a relationship between radon from ingestion of water and } \\
\text { stomach cancers. The risk for stomach cancer from radon was } 0.69 \text { (not significant). }\end{array}$ \\
\hline Italy & $\begin{array}{l}\text { Ground water/ } \\
\text { Volcanic area }\end{array}$ & $\begin{array}{l}1.8-52.7 \mathrm{~Bq} / \mathrm{L} \\
\text { (range) }\end{array}$ & {$[12]$} & $\begin{array}{l}\text { About } 40 \% \text { of the samples }(n=119) \text { exceeded the maximum contaminant level of } 11 \\
\text { Bq/L proposed by the U.S EPA. }\end{array}$ \\
\hline
\end{tabular}




\section{The study area}

Nablus city is located in the north of the West Bank and lies on two high mountains. Nablus citizens are provided by water from the municipality water net that drives the water from the main sources to the customers. Those citizens do not use other sources of water like a well in the house garden that is usually filled from rain or tanks as other cities and villages in the West Bank. Nablus water comes from artesian wells and natural springs. There are 6 wells, 4 main springs and 2 other small springs. Water from these wells and springs is pumped to collecting reservoirs and then to the houses and buildings' reservoirs and finally to the residential taps. There are 22 reservoirs, each reservoir received its water from different wells and springs so water arrived to one house does not come from a single main source. The municipality divides Nablus into 7 regions; each region is supplied mainly by a specific reservoir but this also may be varied according to the availability of water. This means, if there is no enough water in the reservoir; water will be pumped from other reservoir to that reservoir then pumped to the houses. There is an 8th region (old city of Nablus) which is supplied only by one spring called Qaryoon spring.

\section{Sampling framework and data collection}

In this study, samples were collected from the main sources (i.e. wells and springs), and from the residential tap water (selected randomly) in the eight regions of Nablus. The main wells are: Deir Sharaf and Sabstia wells in the northwest region, Badan and Faraa wells in the northeast region and Audala and Rujeeb wells in the southeast region. The springs are: Qaryoon, Ein Beit El Ma, Ein Dafna, Ras Al-Ein, Ein Al-Asal and New reservoir (commercial centre). While the regions or zones of Nablus are: Ein Dafna Zone, Northern Zone, Southern Zone, El Sumara zone, Ein Beit el Ma Zone, Ras Al Ein Zone, reservoir zone and the Old city.

Samples were collected in glass bottles (250 ml each). Three samples were taken from each main source. From each region we took 3 samples from the residential tap water while 10 samples were taken from the old city. Regarding the main sources, we were allowed to collect samples only from 9 sources as 3 of them were closed and were not pumping water at the time we conducted the study. The closed sources were Deir Sharaf well, Rujib well and new reservoir spring.

\section{Experimental setup and measurement procedure}

Research project was approved by the research committee at An-Najah National University faculty of medicine after the approval of the Institutional Review Board (IRB). Nablus municipality approval was also obtained. The researcher then received training in using the DURRIDGE RAD7 $\mathrm{H}_{2} \mathrm{O}$ device following the manual instructions [18]. Therefore, we used RAD water device, an accessory to the RAD7 device manufactured by DURRIDGE Company [18]. It was calibrated on 31 June 2010 and the next calibration time should be done in 31 June 2011.

Briefly, this device offers an accurate measurement, faster reading, it is portable and eliminates the need for noxious chemicals. The schematic diagram of this device is presented in Figure 1 below. Using RAD H2O

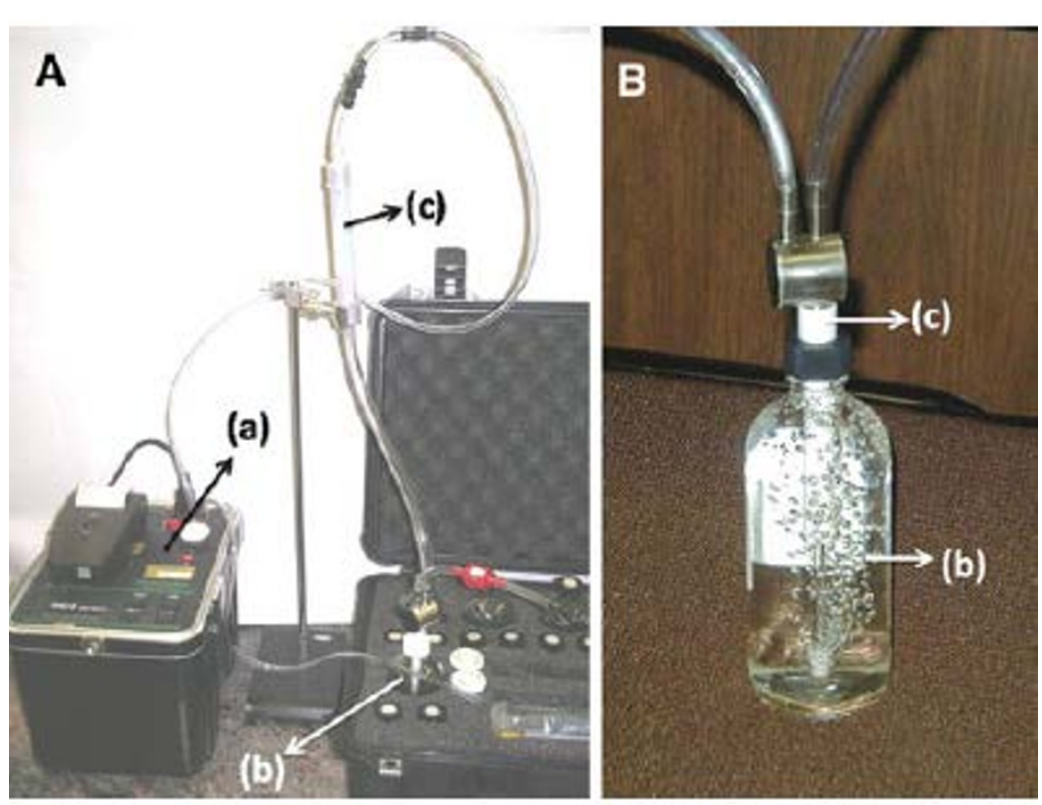

Figure 1 Schematic presentations of radon-in-air monitor RAD-7. Adapted from reference [18] with permission. 
technique employs closed loop concept, consisting of three components; (a) the RAD7 or radon monitor, on the left, (b) the water vial with aerator, in the case near the front, and (c) the tube of desiccant, supported by the retort stand above as marked in the figure.

The RAD-H20 method employs a closed loop aeration scheme whereby the air volume and water volume are constant and independent of the flow rate. The air recirculates through the water and continuously extracts the radon until a state of equilibrium develops. The RAD-H20 system reaches this state of equilibrium within about $5 \mathrm{~min}$, after which no more radon can be extracted from the water. The operation of this device is based on the following principle; (1) radon is expelled from a water sample by using a bubbling kit, (2) expelled radon enters a hemisphere chamber by air circulation, (3) polonium decayed from radon is collected onto a silicon solid-state detector by an electric field and (4) radon concentration is estimated from the count rate of polonium [18].

On the RAD7, one among the two available protocols (i.e., Wat-40 and Wat-250) will be selected depending on the size of vial ( 40 or $250 \mathrm{~mL}$ ) that is being used for water sampling (here we used Wat-250 and sample size of $250 \mathrm{~mL}$ ). This also decides the extraction efficiency or percentage of radon removed from the water to the air loop. For our used protocol of Wat-250, the extraction efficiency was usually very high, typically $95 \%$ for a $250 \mathrm{~mL}$ sample vial [18].

The $250 \mathrm{~mL}$ sample bottle was connected to the RAD7 and the internal air pump of the radon-monitor was used for re-circulating a closed air-loop through the water sample, purging radon from the water into the air-loop. The air is re-circulated through the water continuously to extract the radon until RAD-H2O system reaches a state of equilibrium within about $5 \mathrm{~min}$, after which no more radon can be extracted from the water. After reaching equilibrium between water, air, and radon progeny attached to the passivity implanted planar silicon detector, the radon activity concentration measured in the air loop was used for calculating the initial radon-in-water concentration of the respective sample. The RAD-7 allows determination of radon-inair activity concentrations by detecting the alpha decaying radon progeny Po-218 and Po-214 using passivity implanted planar silicon detector. The radon monitor (RAD-7) uses a high electric field above a silicon semiconductor detected at ground potential to attract the positively charged polonium daughters (Po-218 and Po214) which are counted as a measure of radon- 222 concentration in air.

The pump runs for $5 \mathrm{~min}$, aerating the sample and delivering the radon to the RAD7. The system will wait a further $5 \mathrm{~min}$ and then it starts counting. During the
5 min of aeration, more than $95 \%$ of the available radon is removed from the water and the components automatically perform everything required to determine the radon concentration in the water. After $5 \mathrm{~min}$, it prints out a short-form report.

The same thing is repeated again for 5 min later, and for two more 5-min periods after that. Thus, radon gas is collected through the energy specific windows which eliminate interference and maintain very low backgrounds and later counted for the radon concentration. Radon-222 activities are then expressed with uncertainty down to under $\pm 5 \%$. At the end of the run $(30 \mathrm{~min}$ after the start), the RAD7 prints out a summary, showing the average radon readings from the four cycles, counted a bar chart of the four readings, and a cumulative spectrum.

The RAD H20 enables the measurement of radon in water over a concentration range between 30 and $10^{5}$ $\mathrm{pCi} / \mathrm{L}$ (pico-Curie/liter). The lower limit of detection was less than $10 \mathrm{pCi} / \mathrm{L}$ [18]. The exact value of the extraction efficiency depends somewhat on ambient temperature, but it is almost always well above $90 \%$. Furthermore, the temperature effect on accuracy is usually noticeable with the $250 \mathrm{~mL}$ vial at only very low or high temperatures. The RAD-H20 system has been calibrated for a sample analysis temperature of $20 \mathrm{C}^{\circ}$. In our study, the mean \pm standard deviation $(\mathrm{M} \pm \mathrm{SD})$ temperature value for the wells' and springs' samples was $23.6 \pm 0.74$ and for the residential tap water samples was $20.0 \pm 1.15$. Therefore, a very limited or no effect of temperature was seen on the results.

The RAD7 calculates the sample water concentration by multiplying the air loop concentration by a fixed conversion coefficient that depends on the sample size. This conversion coefficient has been derived from the volume of the air loop, the volume of the sample, and the equilibrium radon distribution coefficient at room temperature. For the $250 \mathrm{~mL}$ sample volume, the conversion coefficient was around 4 [18]. In the analysis, we converted the picocurie $(\mathrm{pCi} / \mathrm{L})$ into Becquerel $(\mathrm{Bq} / \mathrm{L})$ unit using the formula that $1 \mathrm{pCi}=0.037 \mathrm{~Bq}$.

Samples were taken in specific bottles designed for the RAD device and provided by the manufacturer. The collections of the samples and their analysis (for springs and wells) were done between 27th of November 2010 and 4th of December 2010. Tap water sampling and analysis from different regions of Nablus area were done between 7th of December 2010 and 20th of December 2010.

\section{Sample analysis}

To ensure the quality control and reliability of the sampling and measurement methods, each sample was analyzed in 4 cycles. The mean for these 4 cycles was then 
calculated in regard to the wells and springs [see Additional file 1: Wells and springs original data set in $\mathrm{Bq}$ ]. Regarding the residential tap water, we took 3 samples from the houses receiving water from each region using the simple randomization. Each sample was analyzed in 4 cycles where we calculated the mean of these 4 readings and finally we calculated the mean for the 3 samples' means [see Additional file 2: Residential tap water original data set in Bq; see Additional file 3: Old city original data set in $\mathrm{Bq}]$.

Concentrations was measured by $\mathrm{pCi} / \mathrm{L}$ unit as provided by the manufacturer then converted to $\mathrm{Bq} / \mathrm{L}$ for easier comparison with the literatures. Analysis took place at the radon research laboratory at An Najah National University. All samples were analyzed within 3 days of collection because radon half life is 3.8 days [19]. The relative standard deviations of all the 4 cycles analyzed were within the $10 \%$ for their corresponding mean. The SPSS (statistical package for social sciences) software 16 was used for analysis [20].

\section{Results}

\section{Radon levels in the springs and wells}

The results of radon concentration levels in springs and wells are shown in Figure 2. As presented, radon concentrations ranged from 1.5 to $23.4 \mathrm{~Bq} / \mathrm{L}$ with a mean of $6.9 \mathrm{~Bq} / \mathrm{L}$. In springs alone, the mean (range) values were 4.6 (1.5 to 9.9) $\mathrm{Bq} / \mathrm{L}$. In wells however, radon concentration ranged from 2.9 to $23.4 \mathrm{~Bq} / \mathrm{L}$ with a mean of $9.5 \mathrm{~Bq} / \mathrm{L}$. The highest radon concentration was observed in Al-Badan well (mean $\pm \mathrm{SD}$; $23.4 \pm 0.2 \mathrm{~Bq} / \mathrm{L})$.

\section{Radon levels in the residential tap water}

Figure 3, shows the radon concentration levels in the residential tap water in the 7 regions of the Nablus city. The concentration range was from 0.9 to $1.3 \mathrm{~Bq} / \mathrm{L}$ with a mean of $1.0 \mathrm{~Bq} / \mathrm{L}$. We also presented the old city radon concentration levels on the same figure (Figure $3)$. The concentration range for old city was from 0.9 $\mathrm{Bq} / \mathrm{L}$ to $3.8 \mathrm{~Bq} / \mathrm{L}$ with a mean of $2.3 \mathrm{~Bq} / \mathrm{L}$.

In table 2, however, we summarized the minimum, maximum and mean values of radon concentrations in the different assessed sites (springs, wells and tap water) of Nablus city water.

\section{Discussion}

Radon concentration in springs and wells

The main study finding points that all the readings for wells and springs were lower than the U.S maximum contaminated level (MCL) of $11.1 \mathrm{~Bq} / \mathrm{L}$ [15] except for one source (Al-Badan). Although Al-Badan well radon concentration level was higher than the U.S MCL, it remained lower than both the Union reference level set at $100 \mathrm{~Bq} / \mathrm{L}$ [21], and the currently debated U.S. alternative maximum contaminated Level set at $146 \mathrm{~Bq} / \mathrm{L}$ as an

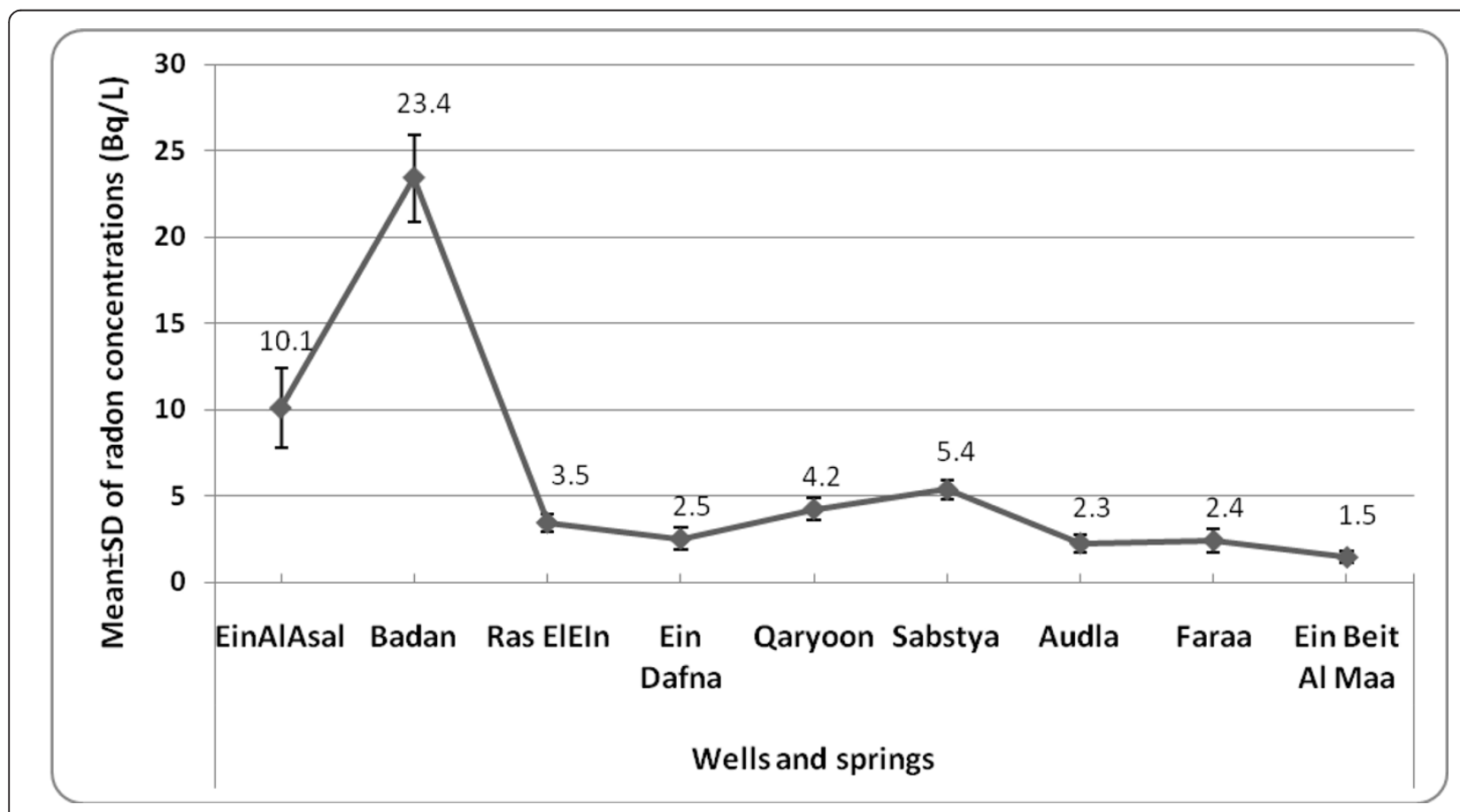

Figure 2 Radon concentrations in Nablus city' springs and wells in Becquerel/L (Bq/L). The bars are related to the means \pm SD values of radon concentrations. 


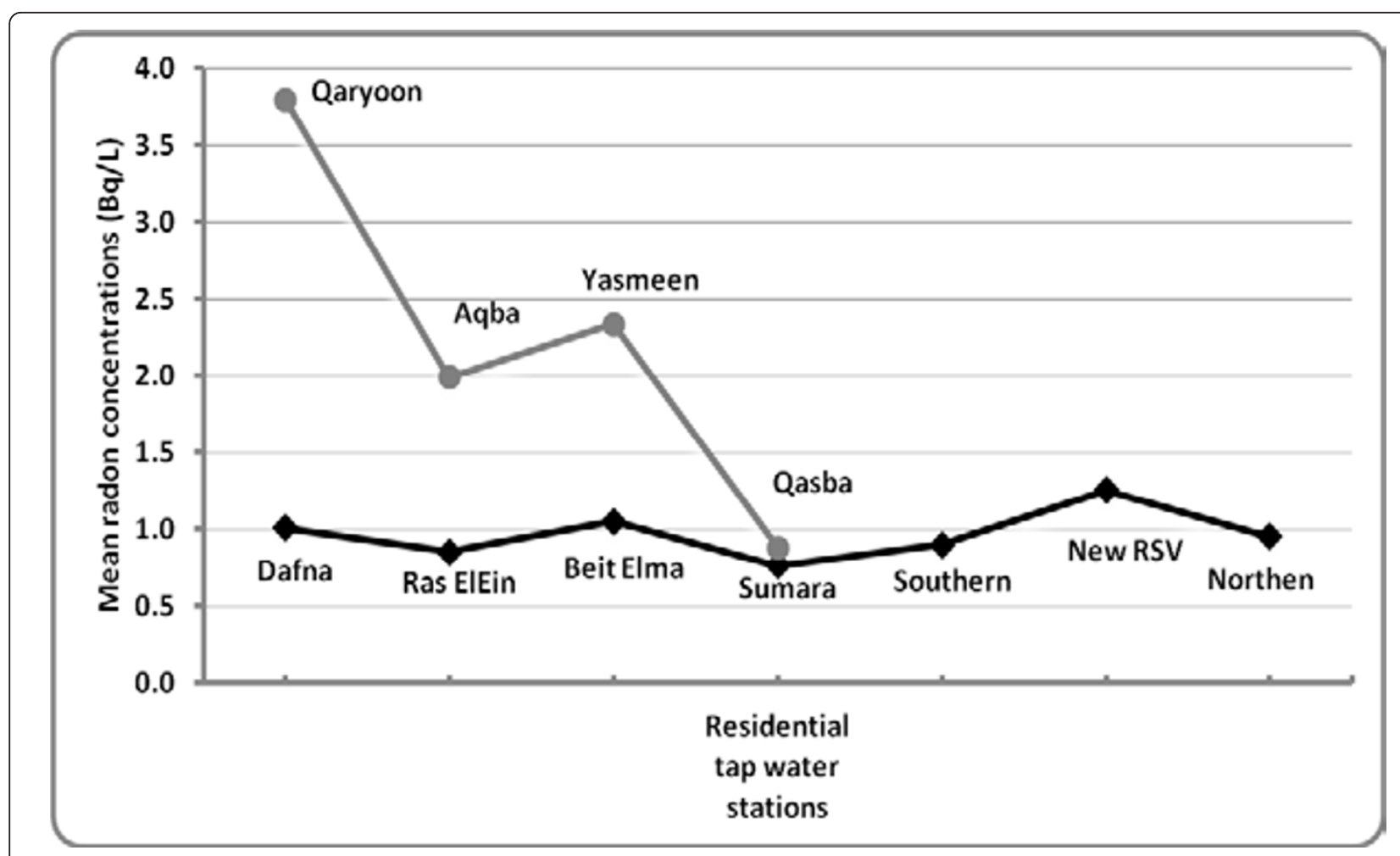

Figure 3 Radon concentrations in the residential tap water of the seven main regions in Nablus city () and in the four different harats (sub-regions) of the old city region () in Becquerel/L (Bq/L).

upper limit for drinking water in the United States. These generally low concentration levels of radon in wells and springs could be explained from the geological context of the surrounding rocks. Indeed, according to the information provided by Nablus municipality, the deepest layer in the studied areas was dolomite, followed by limestone and then chalky stones near the surface. This geological structure was similar for almost all the studied wells and springs. Indeed, uranium and radon are found in small amount in all the types of rocks. However, some types of rocks have more concentration of uranium and radon than others. These include lightcolored volcanic rocks, granites, dark shales, sedimentary rocks that contain phosphate, and metamorphic

Table 2 Maximum, minimum and mean values of radon concentrations in Becquerel/L $(\mathrm{Bq} / \mathrm{L})$ in the different assessed sites of Nablus city water

\begin{tabular}{clll}
\hline $\begin{array}{c}\text { Water assessment } \\
\text { site }\end{array}$ & $\begin{array}{l}\text { Minimum } \\
\text { value }\end{array}$ & $\begin{array}{l}\text { Maximum } \\
\text { value }\end{array}$ & $\begin{array}{l}\text { Mean } \\
\text { value }\end{array}$ \\
\hline Springs & 1.5 & 9.9 & 4.6 \\
\hline Wells & 2.9 & 23.4 & 9.5 \\
\hline Tap water & & & \\
\hline -Seven regions & 0.9 & 1.3 & 1 \\
\hline -Old city & 0.9 & 3.9 & 2.3 \\
\hline
\end{tabular}

rocks derived from these rocks. Dolomite and limestone are sedimentary stones but they are composed of calcium not phosphate which may explain the low concentration values obtained in our study (Dr. Hafez Shaheen, water department in Nablus Municipality, personal communication, June 20, 2011).

However, according to the municipality of Nablus, AlBadan well was closed most of the time within a month prior to the day of sample collection which might explain the relatively high radon concentration in this well. Another possible explanation is that this well is the deepest among others. Usually radon concentration increases as the depth in earth increases [1]. Furthermore and from the geological and geographical point of view, Al-Badan is located closer to the Dead Sea which is considered as a fault zone. Some studies, however, found a relation between high radon concentration in water, soil and air and seismic activities and earth quake. Indeed, the exhalation rate was found to increase near the fault $[11,22,23]$.

Because water pumped to most of the residential areas in Nablus city is mixed in the collecting reservoirs and therefore, there was no specific main area supplied from Al-Badan well, the effect of high concentration level of radon in this well on the residential areas covered in this work was not feasible to be studied. However, 
according to the results that we had from the tap water, we could conclude that there was no increase in the exposure for the general population from Al-Badan well if the municipality continues to supply the water in the current mixing source way.

As there is no absolute safe value of radiation from radon on general public [15], each country had its suggested target safe limit. Although there are few studies on radon level in the outdoor and indoor in Palestine $[14,24,25]$, no water radon level reference has been established and therefore, there has been no specific safe limit value for radon until now in Palestine. Even in the neighbor countries, no standard safe level has been developed and they still depend on the U.S or European standard safe levels. In comparison with radon concentration in Jordan, the mean level for cold spring in Irbid ground water basin was found to be $5.4 \mathrm{~Bq} / \mathrm{L}$. This concentration level is very close to that found in our study (springs, 4.6 Bq/L) [24]. In Lebanon, the mean was found to be around $11.4 \mathrm{~Bq} / \mathrm{L}$ which is within our range values. Another study in Saudi Arabia [26] found that the concentration level ranged from 0.81 to $3.56 \mathrm{~Bq} / \mathrm{L}$. Our findings regarding radon concentrations in spring and wells are in accordance with the previous studies.

\section{Radon concentration in the residential tap water}

Our findings regarding the residential tap water showed that radon concentration levels were less than the main sources. Several factors might explain the findings: radon decay and radon aeration, mixture of water from different sources before pumping, and the travel distance and time could all play a role [21]. As shown in Figure 3, radon concentration levels between the different regions (except for the old city region) are almost around each other. However, the old city concentrations (mainly Harat Qaryoon) were generally higher than the other regions. This variation may be explained by that the old city is supplied only by one spring (Qaryoon spring) which is located in the old city (Qaryoon subregion). Therefore, short and close travel distance and consequently lower decay of radon might explain the higher concentrations observed in the old city in general and Harat Qaryoon in specific.

Compared to other countries, the range for tap water in Jordan was found to be 2.5-4.7 Bq/L. This was slightly higher than our study values but near the range of Harat Qaryoon. Our range was also very close to a Saudi Arabia range values of 0.92-2.12 Bq/L [27] and much similar to that in United Kingdom $(0-2 \mathrm{~Bq} /$ L) [14].

To our concern, the highest level was in Harat Qaryoon, this might reflect a potential high concentration level to the population on long-term exposures. Moreover, the houses in Harat Qaryoon were crowded with poor ventilation and this could play a further role in the potential increased exposure levels.

\section{Conclusions}

Compared with the international references, our findings showed that there was no increase in the exposure of radon in the different drinking water sources in Nablus city. Further studies with larger sample size and different sampling methods might be required to better highlight the exposure levels and risk on the population. As Al-Badan well had a high concentration of radon, further investigations by repeating the measurement or using other method may be needed. We also recommend investigating the radon concentrations in the water sources of other regions in the West bank and Gaza. However, community awareness and education are necessary mainly regarding the ventilation techniques. Attract the attention of the municipality of Nablus city to take preventive measures that could reduce the exposure level of radon in the old city water's supply is also recommended.

\section{Availability of supporting data}

The data sets supporting the results of this article are included within the article (and its additional file (s)).

\section{Additional material}

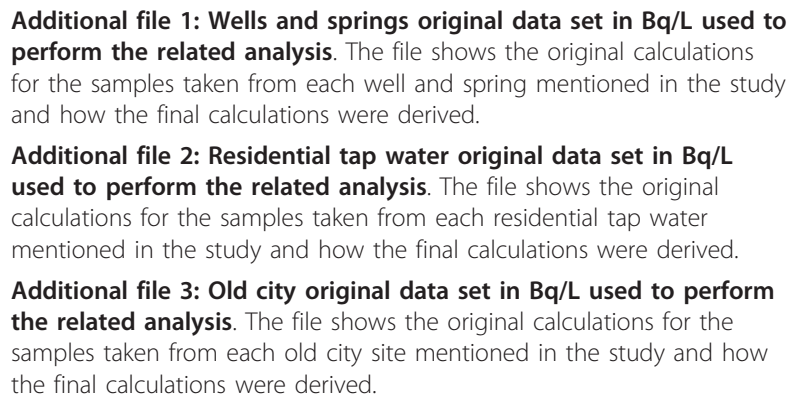

Additional file 1: Wells and springs original data set in $\mathrm{Bq} / \mathrm{L}$ used to perform the related analysis. The file shows the original calculations for the samples taken from each well and spring mentioned in the study and how the final calculations were derived.

Additional file 2: Residential tap water original data set in $\mathrm{Bq} / \mathrm{L}$ used to perform the related analysis. The file shows the original calculations for the samples taken from each residential tap water mentioned in the study and how the final calculations were derived. Additional file 3: Old city original data set in $\mathrm{Bq} / \mathrm{L}$ used to perform the related analysis. The file shows the original calculations for the samples taken from each old city site mentioned in the study and how the final calculations were derived.

\section{Abbreviations \\ USA: United States of America; UK: United Kingdom; U.S EPA: United States Environmental Protection Agency; Bq/L: Becquerel/liter; MCL: Maximum Contaminated Level; pCi: pico-Curie.}

\section{Acknowledgements}

The study was partially granted by the An-Najah National University. We would like to thank the municipality of Nablus for their help and assistance. Special thanks for the head of the municipality Haj Adly Yaeesh and Dr. Hafez Shaheen in the water department for their help and permission to conduct the study. Great and deep thanks for Mr. Ali Qarqash for his help in the collection of samples.

\section{Author details}

${ }^{1}$ Public Health and Community Medicine Department, Faculty of Medicine and Health Sciences, An-Najah National University, Nablus, Palestine. ${ }^{2}$ Faculty of Medicine and Health Sciences, An-Najah National University, Nablus, 
Palestine. ${ }^{3}$ Radiation Physics Laboratory, An-Najah National University, Nablus, Palestine.

\section{Authors' contributions}

HA drafted the manuscript. SM and SI participated in drafting the manuscript. HA, SM and SI performed the statistical analysis and participated in the coordination of the study protocol and study design. ND and GS participated in the study design, protocol and in experimental analysis of samples and provided further contributions and suggestions. All authors read and approved the final manuscript.

\section{Competing interests}

The authors declare that they have no competing interests.

Received: 12 September 2011 Accepted: 13 January 2012

Published: 13 January 2012

\section{References}

1. CDC (Center for Disease Control and Prevention), ATSDR (Agency for Toxic Substances and Disease Registry). Case studies in environmental medicine radon toxicity. 2010, 12:14.

2. Committee on Biological Effects of lonizing Radiation, Board on Radiation Effects Research and Sciences. Health risk of radon and other internally deposited alpha emitters. US: National Acad Press; First 1988:24:26.

3. Alter HW, Price PB: Radon detection using track registration material. US Patent 1972, 3:665-149.

4. Fleisher RL, Giard WR, Mogro-Campero A, Turner LG, Alter HW, Gingrich JE: Dosometry of environmental radon: methods and theory of low dose, integrated measurements. Health Phys 1980, 9:957.

5. Alter HW, Oswald RA: Nationwide distribution of indoor radon measurements. APCA J 1988, 37:227.

6. Committee on Health Risks of Exposure to Radon: health effects of exposure to radon. US: National Acad Press; 1999.

7. WHO handbook on indoor radon a public health perspective. 2009, 1:4

8. Gray A, Read S, McGale P: Lung cancer deaths from indoor radon and the cost effectiveness and potential of policies to reduce them. British Med J 2009, 338:a3110

9. Mustafa A, Patel J, Rathore I: Preliminary Report on Radon Concentration in Drinking Water and Indoor Air in Kenya. Environ Geochem Health 2002, 24:387-396.

10. Al-Bataina BA, Ismail AM, Kullab MK, Abumurad KM, Mustafa H: Radon measurements in different types of natural waters in Jordan. Radiation Meas 1998, 28:591-594.

11. United state environmental protection agency. 2006 [http://www.epa. gov/radon/aboutus.html], Accessed May 20, 2011.

12. EU (European Union) Commission Recommendation on the protection of the public against exposure to radon in drinking water supplies. Office J Eur Community 2001, L 344:85-88.

13. Haquin G, Riemer T, Shamai T, Margaliot M, M Shirav-Schwartz M, Kenett R: Radon Survey of Israel Proceeding of the Conference of Nuclear Societies in Israel, Dead Sea. 2006 [http://www.soreq.gov.il/pdf/pirsumim/ 1407-Radon\%20Survey\%20of\%20lsrael.pdf].

14. Allen J, Geoffrey C, Henshaw L, Keitch P, Perryman J: A UK national survey of radon in domestic water supplies. Phys Educ 1993, 28:173.

15. Auvinen A, Salomen L, Pekkanen J, Pukkala E, Ilus T, Kurttio P: Radon and other natural radionuclides in drinking water and risk of stomach cancer: a case-cohort study in Finland. Int J Cancer 2005, 114:109-113.

16. D'Alessandro W, Vita F: Groundwater radon measurements in the Mt. Etna area, Italy. J Environ Radioact 2003, 65:187-210.

17. Palestinian Central of Bureau and statistics. General Census of Population, Housing, and Establishment 2007; Basic indicators by type of locality. Ramallah - Palestine. 2009.

18. DURRIDGE Company. RAD7, RAD $\mathrm{H}_{2} \mathrm{O}$ accessory owner's manual. [http:// www.durridge.com/documentation/RADH2OManual.pdf].

19. Polpong P, Bovornkitti S: Indoor radon. J Med Assoc Thai 1998, 81:47-57.

20. SPSS Institute Inc: SPSS for window-statistical package for the social sciences, version 16 Chicago, USA: SPSS Institute Inc; 2008.

21. Ismail A, Abu-Samreh M: Seasonal variation measurements of the indoor radon-222 in some villages in East Al-Quds Province, Palestine. Dirasat, Pure Sci 2008, 34:255-263.
22. Singh S, Kumar A, Singh B, Mahajan S, Kumar V, Dhar D: Radon monitoring in soil gas and ground water for earthquake prediction studies in North West Himalayas, India. Terr Atmos Ocean Sci 2010, 21:685-695.

23. Gregoric A, Zmazek B, Vaupotic J: Radon concentration in thermal water as an indicator of seismic activity. Coll Antropol 2008, 32(Suppl 2):95-98.

24. Dwikat N: Indoor radon concentration measurements in four hospitals and two health centers in Nablus city. M.Sc thesis, An-Najah National University; 2001.

25. Abu Samra M: Indoor radon concentration measurements during the summer season of year 2000 in some houses in the western part of Yatta. M.Sc thesis, Al-Quds University; 2001.

26. Kullab M: Assessment of radon-222 concentrations in buildings, building materials, water and soil in Jordan. Appl Radiat Isotopes 2005, 62:765-773.

27. Tayyeb N, Kinsara Rand Farid S: A study on the radon concentrations in water in Jeddah (Saudi Arabia) and the associated health effects. Environ Radioact 1998, 38:97-104.

doi:10.1186/1756-0500-5-29

Cite this article as: Al Zabadi et al:: Exposure assessment of radon in the drinking water supplies: a descriptive study in Palestine. BMC Research Notes 2012 5:29.

\section{Submit your next manuscript to BioMed Central and take full advantage of:}

- Convenient online submission

- Thorough peer review

- No space constraints or color figure charges

- Immediate publication on acceptance

- Inclusion in PubMed, CAS, Scopus and Google Scholar

- Research which is freely available for redistribution 